\title{
A profile of the introduced Oreochromis niloticus (Pisces: Teleostei) populations in Lake Victoria Region in relation to its putative origin of Lakes Edward and Albert (Uganda - E. Africa) based on random amplified polymorphic DNA analysis
}

\author{
Wilson W. Mwanja ${ }^{1 \star}$, Gregory C. Booton ${ }^{2}$, Les Kaufman ${ }^{3}$ and Paul A. Fuerst ${ }^{2}$ \\ ${ }^{1}$ Department of Fisheries Resources, P.O. Box 4 Entebbe, Uganda. \\ ${ }^{2}$ Department of Evolution, Ecology and Organismal Biology, 1735 Neil Avenue, Columbus Ohio 43210, U.S.A. \\ ${ }^{3}$ Boston University Marine Program, Department of Biology, Boston University $5^{\text {th }}$ Cunninng Street, Massachusetts. \\ U.S.A. \\ Accepted 18 January, 2008
}

\begin{abstract}
Random amplified polymorphic DNA (RAPD) marker analyses were used to profile the 'ecological explosion' of the introduced Oreochromis niloticus in the basins of Lakes Victoria and Kyoga in comparison to its putative origin of Lakes Edward, George and Albert. O. niloticus is currently the dominant tilapiine in Lakes Victoria and Kyoga basins following its introductions from the Lakes Albert and Edward starting in the 1920s. The populations from the Lake Victoria basin were more similar to the putative source population of Lake Edward, while the populations from Lake Kyoga were more similar to the Lake Albert population. Lake Kyoga basin populations were less diverse than those of Lake Victoria basin, consistent with the hypothesis that introductions into Kyoga were more recent and/or that a more diverse set of introductions contributed to those of Victoria basin. Wider differences between Lake George and Lake Edward populations relative to distant populations was attributed to the direct transplant of Albert strain into George by a fish processing establishment in the 1970s. RAPDs offered a quick and inexpensive molecular tool to discern fish populations that could be adopted for management of the fisheries given the recent volatile species/populations changes and/or losses in Lake Victoria Region.
\end{abstract}

Key words: RAPDs, Oreochromis niloticus, Lakes Victoria, Kyoga, Edward, Albert, George.

\section{INTRODUCTION}

Lake Victoria Region (LVR), which as defined in Kaufman et al. (1997) includes Lakes Kyoga, Victoria, Edward, George and Kivu, and the immediate surrounding minor satellite lakes and rivers around each of them, has had quite a volatile recent history following the movement of species starting in the early 1900s (Mwanja, 2000). By 1924 Oreochromis niloticus had already been introduced in the LVR via Lake Bunyoni, a satellite lake in the extreme southwestern Uganda, a lake between the

\footnotetext{
*Corresponding author. E-mail: wwmwanja@yahoo.com.
}

George Edward system and LVR (Trewavas, 1983). This was followed by subsequent plantings from either Lake Edward or Lake Albert, directly or via ponds, into many small lakes and dams throughout the LVR (LoweMcConnell, 1958, 1959; Welcome, 1967; Fryer and Iles, 1972). Deliberate introductions were sanctioned for Lakes Kyoga and Nabugabo and their surrounding minor lakes in the late 1950s. O. niloticus is currently the dominant tilapiine in lacustrine habitats throughout the LVR (Ogutu-Ohwayo, 1990; Balirwa, 1992; Mwanja and Kaufman, 1995; Mwanja, 1996, 2000). The protracted frenzy of introductions, plus transplantation of indigenous Lake Victoria species into minor lakes and reservoirs 
Table 1. RAPD Band sharing within and between the LVR O. niloticus populations (not in bold) and similarity indices between populations derived from the band sharing proportions (in bold).

\begin{tabular}{|l|c|c|c|c|c|c|c|c|c|c|}
\hline & Nabugabo & Kachera & Victoria & Kyoga & George & Albert & Nakuwa & Muwuru & Nawampasa & Edward \\
\hline Nabugabo & 0.491 & 0.326 & 0.315 & 0.209 & 0.274 & 0.233 & 0.258 & 0.253 & 0.198 & 0.258 \\
Kachera & $\mathbf{0 . 5 3 4}$ & 0.731 & 0.406 & 0.392 & 0.296 & 0.264 & 0.401 & 0.382 & 0.226 & 0.250 \\
Victoria & $\mathbf{0 . 5 2 0}$ & $\mathbf{0 . 5 5 9}$ & 0.722 & 0.333 & 0.352 & 0.265 & 0.396 & 0.368 & 0.319 & 0.247 \\
Kyoga & $\mathbf{0 . 3 6 2}$ & $\mathbf{0 . 5 6 0}$ & $\mathbf{0 . 4 8 0}$ & 0.667 & 0.357 & 0.259 & 0.430 & 0.402 & 0.364 & 0.309 \\
George & $\mathbf{0 . 4 6 7}$ & $\mathbf{0 . 4 1 9}$ & $\mathbf{0 . 5 0 0}$ & $\mathbf{0 . 5 2 9}$ & 0.683 & 0.400 & 0.421 & 0.369 & 0.409 & 0.271 \\
Albert & $\mathbf{0 . 4 0 3}$ & $\mathbf{0 . 3 7 9}$ & $\mathbf{0 . 3 8 2}$ & $\mathbf{0 . 3 9 0}$ & $\mathbf{0 . 5 9 4 ^ { \star }}$ & 0.664 & 0.301 & 0.387 & 0.233 & 0.176 \\
Nakuwa & $\mathbf{0 . 4 0 5}$ & $\mathbf{0 . 5 3 0}$ & $\mathbf{0 . 5 2 5}$ & $\mathbf{0 . 5 9 4}$ & $\mathbf{0 . 5 7 3}$ & $\mathbf{0 . 4 1 6}$ & 0.785 & 0.643 & 0.378 & 0.322 \\
Muwuru & $\mathbf{0 . 3 7 4}$ & $\mathbf{0 . 4 7 9}$ & $\mathbf{0 . 4 6 5}$ & $\mathbf{0 . 5 2 6}$ & $\mathbf{0 . 4 8 8}$ & $\mathbf{0 . 5 0 7}$ & $\mathbf{0 . 7 8 0}$ & 0.863 & 0.278 & 0.272 \\
Nawampasa & $\mathbf{0 . 3 2 9}$ & $\mathbf{0 . 3 1 3}$ & $\mathbf{0 . 4 4 5}$ & $\mathbf{0 . 5 2 9}$ & $\mathbf{0 . 5 8 7}$ & $\mathbf{0 . 3 4 0}$ & $\mathbf{0 . 5 0 6}$ & $\mathbf{0 . 3 5 3}$ & 0.710 & 0.232 \\
Edward & $\mathbf{0 . 3 8 1}$ & $\mathbf{0 . 3 7 2}$ & $\mathbf{0 . 3 7 0}$ & $\mathbf{0 . 4 8 2}$ & $\mathbf{0 . 4 1 9}$ & $\mathbf{0 . 2 7 5}$ & $\mathbf{0 . 4 6 0}$ & $\mathbf{0 . 3 6 9}$ & $\mathbf{0 . 3 5 9}$ & 0.613 \\
\hline
\end{tabular}

*Highlights the similarity indices between the populations known to be the putative origins of $O$. niloticus into other lakes in the LVR. Notable is the high similarity between Lakes Albert and George as compared to Lakes Edward and George which are geographically much closer.

within the LVR, created a complex web of more or less isolated tilapiine subpopulations (Mwanja et al., 1995). This tortured history greatly complicates the identification of genetically meaningful units for conservation or management. Local differentiation of tilapia phenotypes is sometimes apparent by eye, but there are few quantitative data - genetic, ecological, or morphological - to support this contention.

Here we profile the population structure of naturalized $O$. niloticus in the LVR using random amplified polymerphic DNA (RAPD) technique (Hedrick, 1992; Dawson et al., 1993; Russell et al., 1993), which though of limited value in availing genetic indices is quite appropriate in profiling and comparing recent fish population histories especially when the analysis is done at the same time under similar laboratory conditions. Bardakci and Skibinski (1994) and Naish et al. (1995), have previously reported successful use of the RAPD technique in identifying subspecies and strains of $O$. niloticus. It was also used successfully to profile tilapiine populations in the LVR (Mwanja et al., 1997; Mwanja, 1996).

\section{METHODS AND MATERIALS}

\section{Study area}

Samples were obtained from selected lakes in the Lake Victoria basin and Lake Kyoga basin, and from Lakes Edward George and Albert (Table 1). Lake Victoria and Lake Kyoga basins plus Lakes Edward, George, Kivu, and scores of satellite minor around these lakes comprise the Lake Victoria Region (Kaufman et al., 1997).

For the purpose of this study, each lake was assumed to contain a single panmictic population of $O$. niloticus.

\section{Molecular methods}

DNA extraction was performed using the standard phenol/ chloroform extraction method (Sambrook et al., 1989). PCR reaction mixtures of $25 \mu \mathrm{l}$ final volume containing $50 \mathrm{ng}$ of genomic
DNA, and final concentration of $25 \mu \mathrm{M}$ of dNTP, $0.6 \mu \mathrm{M}$ of primer $2.5 \mu \mathrm{l}$ of a reaction buffer, and $0.1 \mu \mathrm{l}$ of $5 \mathrm{U} / \mu \mathrm{l}$ Taq polymerase enzyme from BRL technologies. RAPD decamer primers (Operon Technologies, Alameda, California) were used in a Perkin-Elmer thermocycler at the following sequence: a hot start for $3 \mathrm{~min}$ at $94^{\circ} \mathrm{C}$, then 45 cycles for $30 \mathrm{~s}$ at $94^{\circ} \mathrm{C}, 1 \mathrm{~min}$ at $35^{\circ} \mathrm{C}$, and 2 min at $72^{\circ} \mathrm{C}$, with a 10 min extension at $72^{\circ} \mathrm{C}$ at the end of the 45 cycles. Repeatability and potential contamination of reaction conditions were checked using both a positive and a negative control for every reaction set, for each primer. All sets of reactions were based on the same stock DNA extract diluted independently to $50 \mathrm{ng}$ of genomic DNA for each PCR reaction mixture. Amplifications were separated by $1.6 \%$ agarose synergel electrophoresis, and visualized under UV light after ethidium bromide staining.

\section{Data analysis}

RAPD band presence/absence in single individuals was used as character data to investigate the phylogeographic relationships of the populations. Populations were also analysed for occurrence of unique bands (bands that occurred exclusively in one population or only in a particular set of populations) and rare bands (bands with a frequency of $<0.1$ ). Populations were also analysed for the number and proportion of polymorphic loci/bands, which were determined as all loci that had equal or less than $95 \%$ frequency. Band sharing proportions, similarity indices, and genetic distances were estimated following Bardakci and Skibinski (1994) and Naish et al. (1995).

\section{RESULTS}

A total of 177 reproducible bands were generated for the 11 populations (Table 1). At a higher level, populations from the Kyoga basin and Victoria basin shared more bands among populations of the same basin and relatively higher similarity indicies (Kyoga basin: Kyoga and Nakuwa lakes $=0.594$, Kyoga and Muwuru lakes = 0.569 , Kyoga and Nawampasa lakes $=0.529$, Nakuwa and Muwuru lakes $=0.780$, Nakuwa and Nawampasa lakes $=0.506$; Victoria basin: Victoria and Nabugabo 
Table 2. Allele frequency population attributes for O. niloticus populations of the LVR.

\begin{tabular}{|c|c|c|c|c|c|c|c|c|c|c|c|c|c|c|}
\hline \multirow{2}{*}{$\begin{array}{l}\text { Band frequency } \\
\text { attributes/Population }\end{array}$} & \multicolumn{2}{|c|}{$\begin{array}{l}\text { Unique } \\
\text { Alleles }\end{array}$} & \multicolumn{2}{|c|}{ Monomorphism } & \multicolumn{2}{|c|}{ polymorphism } & \multicolumn{2}{|c|}{$\begin{array}{c}\text { Null } \\
\text { bands }\end{array}$} & \multicolumn{2}{|c|}{$\begin{array}{c}\text { Rare } \\
\text { bands }\end{array}$} & \multicolumn{2}{|c|}{$\begin{array}{l}\text { Rare bands } \\
\text { absent in } L . \\
\quad \text { Albert }\end{array}$} & \multicolumn{2}{|c|}{$\begin{array}{l}\text { Rare bands } \\
\text { absent in L } \\
\text { George }\end{array}$} \\
\hline & No. & $\%$ & No. & $\%$ & No. & $\%$ & No. & $\%$ & No. & $\%$ & No & $\%$ & No. & $\%$ \\
\hline Nabugabo & 0 & 0.0 & 0 & 0.0 & 46 & 26.0 & 131 & 74.0 & 11 & 6.2 & 15 & 79.0 & 10 & 100 \\
\hline Kachera & 2 & 1.1 & 13 & 7.4 & 38 & 21.5 & 126 & 71.2 & 6 & 3.4 & 13 & 68.4 & 10 & 100 \\
\hline Victoria & 4 & 2.3 & 12 & 6.8 & 49 & 27.7 & 116 & 65.5 & 13 & 7.3 & 16 & 84.2 & 9 & 90.0 \\
\hline Kyoga & 8 & 4.5 & 12 & 6.8 & 66 & 37.3 & 99 & 55.9 & 13 & 7.3 & 13 & 68.4 & 7 & 70.0 \\
\hline George & 3 & 1.7 & 10 & 5.7 & 64 & 36.2 & 103 & 58.2 & 10 & 5.7 & 15 & 79.0 & - & - \\
\hline Albert & 16 & 9.0 & 12 & 6.8 & 80 & 45.2 & 85 & 48.0 & 19 & 10.7 & - & - & 5 & 50.0 \\
\hline Nakuwa-Muwuru & 8 & 4.5 & 24 & 13.6 & 84 & 47.5 & 69 & 39.0 & 15 & 8.5 & 14 & 73.7 & 1 & 10.0 \\
\hline Edward & 3 & 1.7 & 12 & 6.8 & 41 & 23.2 & 124 & 70.1 & 14 & 7.9 & 13 & 68.4 & 8 & 80.0 \\
\hline
\end{tabular}

lakes $=0.520$, Victoria and Kachera lakes $=0.559$, Nabugabo and Kachera lakes $=0.534$ ), than between the two basins (between basins: Nabugabo and Kyoga lakes $=0.362$, Nabugabo and Nakuwa lakes $=0.405$, Nabugabo and Muwuru lakes $=0.374$, Nabugabo and Nawampasa lakes $=0.329$, Victoria and Kyoga lakes $=$ 0.480 , Kachera and Muwuru lakes $=0.479$, Kachera and Nawampasa lakes $=0.313$ ). Populations within Lake Victoria basin had higher band sharing with Lake George populations (Range of similarity indices of 0.419 to 0.500 ) than with Lake Albert and Lake Edward populations (Range of similarity indices of 0.379 to 0.403 for Albert, and 0.370 to 0.380 respectively), while those of Lake Kyoga basin shared more with Lake George population (range of similarity indices of 0.488 to 0.587 ) than that from Lake Edward (range of similarity indices of 0.369 to 0.460 ) or Lake Albert (range of similarity indices of 0.340 to 0.507 ). Lake Albert and Lake Edward were apparently the most different (similarity indice of only 0.275) (Table 1). Populations from LVR had higher similarity indices to the Lake George population than to either L. Edward or L. Albert populations. There was also a higher similarity between populations from Lakes George and Albert than between those of Lakes George and Edward. Table 2 shows level of polymorphism, number and percentage of rare bands; number and percentage of null bands; number and percentage of monomorphic bands; number and percentage of rare bands of populations from Albert and George that did not occur in the other populations; and the number and percentage of unique (population specific) bands carried by each population. The populations were significantly different in the number of rare bands as well as the proportion of null bands $\left(\mathrm{X}^{2}, \mathrm{P}=\right.$ $0.05)$. There were also wide differences in the proportion of Lake George population rare bands that were missing in each of the other populations, whereas there were no differences in proportion of rare bands of $\mathrm{L}$. Albert population not found in the rest of the populations $\left(\mathrm{X}^{2}, \mathrm{P}\right.$ $=0.05$ ). However, Lake Albert population exhibited rela- tively higher number of unique bands as well as rare bands when the nine populations were compared. The combined population of Lakes Nakuwa and Muwuru from Lake Kyoga showed comparably higher levels of monomorphic bands but also had a higher level of polymorphism (Table 2). Lake Victoria basin populations had comparably lower levels of polymorphism than populations from Lake Kyoga basin and Lake EdwardAlbert system. Likewise Lake Victoria basin populations exhibited a greater loss of Lake George population rare bands as compared to moderate loss in Lake Kyoga basin populations (Table 2). The Lake Edward population showed higher similarity in all attributes studied to Lake Victoria basin populations than to populations from Lake Kyoga basin. Genetic distances calculated from band sharing proportions were used to determine relationships among the nine populations (Figure 1). The Lakes Kyoga, George and Albert populations were apparently closer to each other than any of them were with Lake Edward population. Lake Mburo population, among the earliest water bodies stocked with Edward O. niloticus strain was the closest to the Edward population.

\section{DISCUSSION}

O. niloticus is remarkable for its functional versatility and labile ecology (Fryer and Iles, 1972; Trewavas, 1983; Sanderson et al., 1996; Batjakas et al., 1997). This, together with its great adaptability to virtually all tropic and subtropic environments, explains its position among the top aquaculture species in the world. The successful evolution of $O$. niloticus fishery in the Lake Victoria in face of the introduced voracious predator - Nile perch (Lates niloticus), is credited to several factors: a long history of co-existence with the Nile perch in its native range both in Lake Turkana and Lake Albert; trophic virtuosity, allowing access to a wide range of ecological niches; and ability to breed under conditions that conge- 


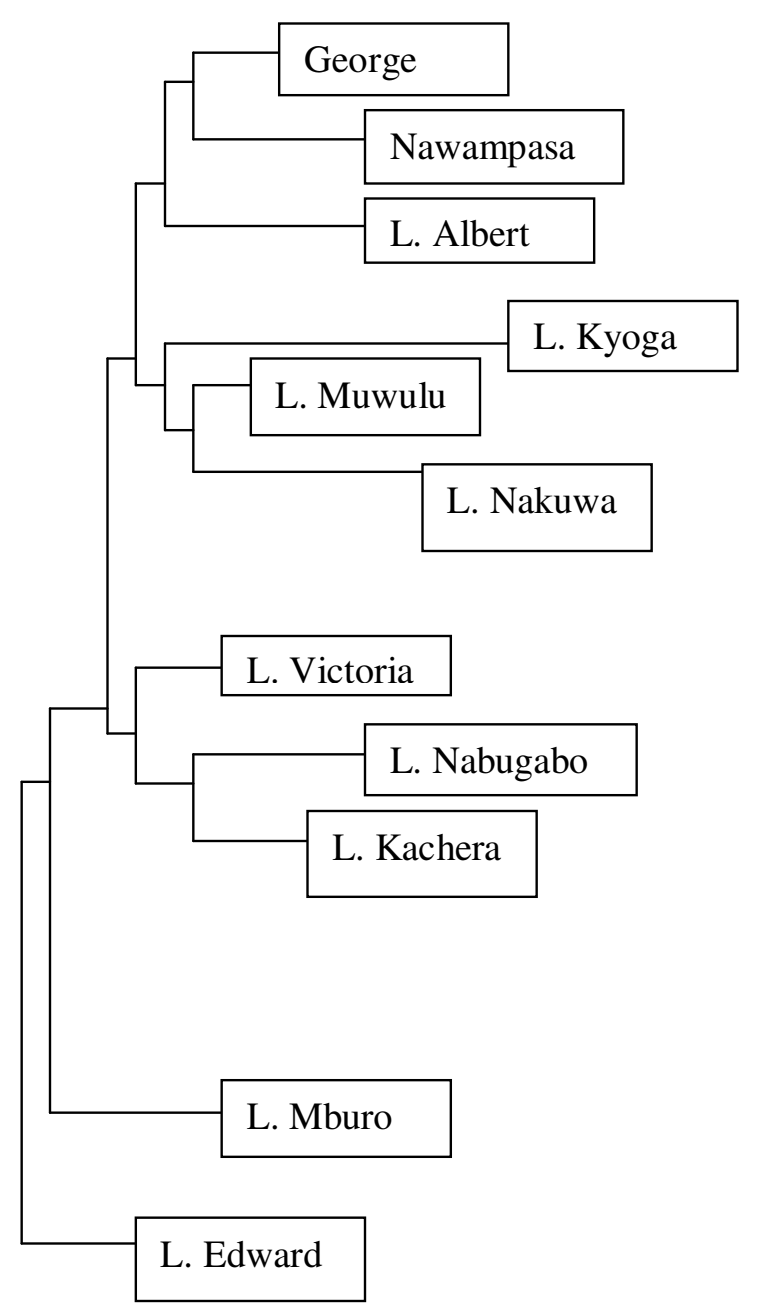

Figure 1. An rooted dendogram of Oreochromis niloticus populations from 11 lakes of Lake Victoria Region constructed from genetic distances derived from RAPD band sharing proportions.

ners and other species would not tolerate, such as high littoral turbidity due to deforestation (Balirwa, 1992). Several tilapiine species were introduced into LVR together with $O$. niloticus, but none of the others has been as successful in establishing as $O$. niloticus. The profile of $O$. niloticus populations shows segregation largely by basins but with considerable variation among populations within a basin. The extant Lake Victoria metapopulation appears to have largely descended from Lake Edward stock than from Lake Albert, if not, it is a reflection of how modified the Victoria metapopulation has become. The Lake Victoria population may also be reflection of the multiple seed source used in the introduction, and interaction between $O$. niloticus with both the native and other introduced tilapiines (Mwanja, 1996). O. niloticus is known to be ecologically versatile and aggressive species (Balirwa 1992), and has been found to ecologically overrun closely related forms once established in new environments (Lowe-McConnell,
1959; Welcomme, 1967). When O. niloticus becomes dominant it was found to genetically swamp the conspecifics and displace the natives out of the water bodies in which the two species co-exist (Leveque, 1997; Lowe-McConnell, 1987; Mwanja 1996). The Kyoga metapopulation appears more predominantly to have been founded by Lake Albert strain, and/or may reflect a much recent introduction history out of this source compared to Lake Victoria metapopulation.

The closer similarity between $O$. niloticus populations of Lake George and Lake Albert, than between those of Lake George and Lake Edward, though troubling, is that $O$. niloticus populations in Lake George have been influenced by introductions of stock from Albert with the establishment of a fish processing facility in the first attempt to farm and process Ugandan Fish by Lake George in the 1970s. Doubt to movement of species and the strong mark in enormous lake systems left by anthropogenic translocating of fish species is greatly diminished by our recent discovery of both threatened Oreochromis esculentus and the exotic Tilapia rendalli populations in Lake Edward-George system (Mwanja, 2000; Mwanja et al. 2007). Neither of the two species had ever been recorded before, and neither occurs there naturally (Fryer and Iles, 1972; Trewavas, 1983). The historical biogeography of fishes in East Africa will always be of great interest due to its fascinating evolutionary implications.

Pressure on fisheries stocks in Lake Victoria Region (LVR) by early 1950's prompted resource managers to begin widespread introduction and transplanting of fish species into Ugandan waters (Welcomme, 1967; Fryer and lles, 1972). The fisheries of Lake Victoria and Lake Kyoga are currently dominated by two introduced species, Nile perch and Nile tilapia, and one native small minnow, Rastrineobola argenta, while the previous highlights of the fisheries, the two endemic tilapiines of the LVR, have been displaced out of the main lakes and are relegated to the minor satellite lakes (Mwanja, 2000). The introduced species explosion in abundance has had visible and appreciable immediate and may be long-term socio-economic benefits. However, the explosion of the introduced species has significantly and perhaps irreversibly changed the ecology and evolution of the fisheries of LVR waters.

\section{REFERENCES}

Balirwa JS (1992). The evolution of the fishery of Oreochromis niloticus (Pisces: Cichlidae) in Lake Victoria. Hydrobiologia 232: 58-89.

Batjakas IE, Edgar RK, Kaufman LS (1997). Comparative feeding efficiency of indigenous and introduced phytoplanktivores from Lake Victoria. Experimental studies on Oreochromis esculentus and Oreochromis niloticus. Hydrobiologia. 347(1-3): 75-85.

Bardakci F, Skinbinski DOF (1994). Application of RAPD technique in tilapia fish: species and subspecies identification. Heredity, 73: 117123.

Dawson IK, Chambers KJ, Waugh R, Powell W (1993). Detection of genetic variation in Hordeum spontaneum population of Israel using RAPD markers. Mol. Ecol. 2: 151-159. 
Fryer G, Iles TD (1972). The Cichlid Fishes of the Great Lakes of Africans. Oliver and Boyd, Edinburgh.

Hedrick P (1992). Shooting RAPDS. Nature pp. 355, 679-680.

Kaufman L (1992). Catastrophic change in Species-Rich Freshwater Ecosystems. Bioscience. 42(11): 846-858

Kaufman L, Chapman CA, Chapman LJ (1997). Evolution in fast forward:haplochromine fishes of the Lake Victoria region. Endeavour (London) 21(1): 23-30.

Leveque C (1997). Biodiversity dynamics and conservation: the freshwater fish of tropical Africa. Cambridge University Press, Cambridge UK.

Lowe-McConnell RH (1958). Observations on the biology of Tilapia nilotica (Pisces: Cichlidae) in East African waters. Revue Zool. Bot. Afr. 57:129-170

Lowe-McConnell RH (1959). Breeding behaviour patterns and ecological differences between species and their significance for evolution within the genus Tilapia (Pisces, Cichlidae). Proc. Zool. Soc. London, 132(1): 1-30.

Lowe-McConnell RH (1987). Ecological studies in tropical fish communities. Cambridge University Press, Cambridge, p. 124.

Mwanja W, Kaufman L (1995). A note on recent advances in genetic characterization of tilapia stocks in Lake Victoria Region. Afr. J. Trop. Hydrobiol. Fish 6: 51-55.

Mwanja W (1996) Genetic variability and population structure of the tilapiine fauna of the Lake Victoria Basin (Uganda) in relation to exotic species introduction. MSc. Thesis, Ohio State University, Columbus Ohio. p.102

Mwanja W, Bugenyi F, Kaufman L (1997). Genetic characterization of tilapiine stocks in the Lake Victoria Region, p33-34. In Pullin RSV, Casal CMV, Abban EK, Falk TM (eds) Characterization of Ghanaian tilapia genetic resources for use in fisheries andaquaculture. ICLARM Conf. Proc. pp. 52, 58.

Mwanja WW (1996). Genetic Variability and Population Structure of Tilapiine Fauna of Lake Victoria Basin (Uganda) in Relation to Exotic Species Introductions. Master of Science thesis p. 125. The Ohio State University, Columbus, Ohio.

Mwanja WW (2000). Genetic Biodiversity and Evolution of Two Principal Fisheries Species Groups, the Labeine and Tilapiine, of Lake Victoria Region, East Africa. PhD Thesis, Ohio State University, Columbus Ohio, p. 264.
Mwanja WW, Booton CG, Kaufman L, Fuerst PA (2007). The Collapse of the Ngege, Oreochromis esculentus (Teleostei: Cichlidae) populations, and resultant population genetic status in the Lake Victoria and Lake Kyoga Basins. Afr. J. Aquatic Sci. (In press).

Naish KA, Warren M, Bardakci F, Skibinski DOF, Carvalho GR, Mair GC (1995). Multilocus DNA fingerprinting and RAPD reveal similar genetic relationships between strains of Oreochromis niloticus (Pisces: Cichlidae). Mol. Ecol. 4: 271-274.

Ogutu-Ohwayo R (1990). The decline of the native fishes of lakes Victoria and Kyoga (East Africa) and the impact of introduced species, especially the Nile perch, Lates niloticus, and the Nile tilapia, Oreochromis niloticus. Environ. Biol. Fish 27: 81-96.

Russell JR, Hosein E, Waugh R, Powell J (1993). Genetic differentiation of cocoa (Theobroma cacoa L.) populations revealed by RAPD analysis. Mol. Ecol. 2: 89-97.

Sambrook J, Fritsch EF, Maniatis T (1989). ( $2^{\text {nd }}$ Ed) Molecular cloning: a laboratory manual. Cold Spring Press, Cold Springs Habor, New York.

Sanderson SL, Steber MC, Ackerman LL, Jones SH, Batjakas IE, Kaufman L (1996). Mucus entrapment of particles by a suspension feeding tilapia (Pisces: Cichlidae). J. Exp. Biol. 199: 1743-1756.

Trewavas E (1983). (Ed.) Tilapiine fishes of Genera Sarotherodon, Oreochromis, and Danakila. British Museum (Natural History) publication, p. 878.

Welcomme RL (1967). Observations on the biology of Introduced species of Tilapia in Lake Victoria. Revue. Zool. Bot. Afr. 76(3-4): 249279. 